\title{
GRAMÁTICA DO PORTUGUÊS CULTO FALADO NO BRASIL: VOLUME 2: A CONSTRUÇÃO DA SENTENÇA
}

Gláucia Xavier ${ }^{*}$

KATO, Mary A.; NASCIMENTO, Milton do (Org.). Gramática do português culto falado no Brasil: volume 2: a construção da sentença. São Paulo: Contexto, 2015.

"A construção da sentença" é uma obra escrita por grandes pesquisadores da área da Sintaxe como Mary Kato, Milton do Nascimento, Carlos Mioto, Jairo Nunes, Ruth Lopes e outros que se dedicam ao estudo e compreensão da formação da sentença. Nesse trabalho, os organizadores e autores dos capítulos souberam, com talento, expor o tema "sintaxe" a professores e estudantes da língua em um formato repaginado. O livro subdivide a sentença em partes a serem debatidas e explicadas como complementação, predicação e adjunção. Os capítulos tratam a sintaxe de maneira diferente da vista pela gramática normativa. Apesar de não deixar explícito o viés marcadamente gerativista, a obra apresenta como a sentença é construída em nossa gramática mental, de acordo com os pressupostos da Teoria Gerativa.

O que torna a obra oportuna é o fato de diferenciar a sentença, que é algo abstrato, do enunciado (p. 14). Isso é feito de forma leve e de fácil compreensão. Contrariamente a muitos textos gerativistas, o volume em estudo consegue expor sobre a formação da sentença sem complexidade e consegue relacionar sintaxe e discurso com uma explicação unificada (p.233), chamada pelos autores de "interface sintaxe-discurso". A proposta da obra é "tomar os eixos semântico e sintático não como excludentes, mas como complementares"(p.39).

De forma prática, os temas são tratados sob diversas perspectivas. Usa-se do desempenho do falante para explicar sua competência linguística e como isso ocorre no momento da formação da sentença. Conjuntamente e a partir da sintaxe, analisa-se como a semântica se dá. Os autores afirmam que as generalizações semânticas são determinadas pela estruturação da relação do predicador e seus argumentos (p.39).

Alguns temas que já se faziam urgente ao debate são trazidos como, por exemplo, o entendimento dos verbos inacusativos e inergativos (a partir da p. 48), que conforme os autores postulam, é um dos temas sobre estudos gramaticais mais interessantes em análise nas últimas décadas. A noção de verbo intransitivo torna-se insuficiente quando nos deparamos com sentenças como "Os últimos combatentes sumiram" (p.49). O que os autores reafirmam é que a categoria de verbos monoargumentais apresenta duas classes distintas, a dos verbos que selecionam apenas argumento interno e a dos verbos que selecionam apenas argumento externo.

Tema de grande relevância na interface sintaxe-semântica é o da atribuição do papel temático aos argumentos de uma sentença e a realização sintática deles, incluindo o estudo da metáfora (p. 43). Outro ponto positivo é o fato de a obra descrever mudanças ocorridas no Português Brasileiro e tentar explicá-las (p.118). Por vezes, isso é feito a partir da comparação da gramática tradicional com os estudos sintáticos. Essa comparação é bem vista, pois

Doutora em Linguística e Língua Portuguesa pela PUC-MG, professora de dedicação exclusiva do Instituto Federal de Minas Gerais. glaucia. xavier@ifmg.edu.br

Instrumento: R. Est. Pesq. Educ., Juiz de Fora, v. 19, n. 1, jan./jun. 2017 
localiza o leitor e ajuda-o a compreender determinadas operações que ocorrem no Sistema Computacional durante a construção das sentenças. Há determinados trechos que não só há a comparação da gramática normativa com a gramática mental, como também a explicação de fenômenos, como o da clivagem, ausentes na gramática normativa (p.197).

Semelhante à Teoria Gerativa, o livro explora tanto o poder descritivo quanto o poder explicativo da construção da sentença. Há capítulos, como o da "Complementação" que são muito explicativos, com o desenho de árvores sintáticas e sua estrutura de ramificação binária, tão característica do gerativismo. Já o capítulo seguinte, sobre "Predicação", apresenta trechos bem descritivos com muitos exemplos do Projeto da Norma Urbana Oral Culta (NURC). Não obstante, sentimos falta do reconhecimento da categoria aspecto, já tão solidificada nos estudos gramaticais. $\mathrm{O}$ aspecto só é abordado ao final, no capítulo Adjunção (a partir da p. 160), sendo ignorado nos capítulos "Complementação" e "Predicação". É também só no final da obra, no capítulo sobre "Relativas, clivadas e interrogativas" que, pela primeira vez, há a manifestação, no corpo do texto, a respeito da literatura gerativista (p.214).

Uma sugestão que poderíamos deixar para os autores, quando estudamos sintaxe no viés de uma estrutura mental, é que as árvores não devem ser economizadas. Elas são altamente ilustrativas e imprescindíveis, principalmente para alunos de graduação e pós-graduação quando querem compreender como a sentença é construída. Mesmo havendo a presença de muitas árvores, elas fizeram falta no estudo das pseudoclivadas (p.221), no estudo das sentenças que contém verbos transitivos, auxiliares e leves (p.75), no capítulo "Adjunção" e também no caso dos verbos psicológicos refratários à passivização.

Ao final, o capítulo de "Adjunção" demonstra que os adjuntos não são tão acessórios como parecem. A obra postula que, sob um viés sintático, eles não são tão livres e nem sempre podem ocupar qualquer posição na sentença. O que se nota é que eles "são elementos bem comportados no que se refere a posiçóes que possam ocupar" (p.156). O desfecho ocorre quando a adjunção é considerada, pelos autores, como uma operação que conecta as regras sintáticas a maneiras do seu uso, chegando a uma dupla face da adjunção (p.245) a qual conecta as propriedades da Língua-I à organização dos enunciados.

Em suma, "A construção da sentença" não pode faltar na biblioteca dos sintaticistas, pois aborda as questóes sintáticas e explica detalhadamente como a sentença é formada, de que maneira um predicador seleciona seus argumentos, como e "onde" ocorre a atribuição de papéis temáticos e como as operações de movimentos sintáticos ocorrem no Sistema Computacional. Todos esses processos sintáticos são debatidos, assim como o uso da língua, ou seja, tanto a competência quanto o desempenho estão presentes no conteúdo da obra. De fato, os autores conseguiram demonstrar como a interface sintaxe-discurso abrangem as funções sintáticas de predicação, complementação e a dupla face da adjunção.

Recebido em 6 de dezembro de 2016. Aprovado em 30 de janeiro de 2016. 